\title{
Effect of Open Note Quizzes on Community College Science Students Grades and Attrition Rates
}

\author{
Maureen N. Gannon ${ }^{1} \&$ Abass S. Abdullahi ${ }^{1, *}$ \\ ${ }^{1}$ Department of Biology and Medical Laboratory Technology, Bronx Community College of the City University of \\ New York, Bronx, NY 10453, USA \\ *Corresponding author: Department of Biology and Medical Laboratory Technology, Bronx Community College of \\ the City University of New York, 2155 University Avenue, Bronx, NY 10453, USA. E-mail: \\ Maureen.Gannon@bcc.cuny.edu; Abass.Abdullahi@bcc.cuny.edu
}

Received: April 22, 2013

Accepted: May 27, 2013

Online Published: July 11, 2013

doi:10.5430/jct.v2n2p1

URL: http://dx.doi.org/10.5430/jct.v2n2p1

\begin{abstract}
This article describes the effectiveness of open note quizzes in improving student outcomes in an introductory Human Anatomy and Physiology course. Results are discussed within the context of a teaching strategy called LETME (Link, Extract, Transform, Monitor and Extend), which was specifically developed for at risk community college students. The use of open note quizzes not only helped students monitor their progress, but also with note taking as they extracted and transformed information from the textbook and other sources. It also enabled them to link this information to previous knowledge and extend it to new concepts. In addition to achieving significantly higher test scores in the five lecture tests and overall grades, students exposed to LETME reported slightly better study habits in monitoring their own performance and their independent study skills. For instance, surveys indicated that they were more likely to use their textbook, take notes and be involved with study groups. The experimental group also reported that the open note quizzes helped them in preparing for exams and mastering the course. Students in the experimental group were also more likely to complete the course than the general student population.
\end{abstract}

Keywords: student outcomes; at risk students; open note quizzes; anatomy \& physiology

\section{Introduction}

A lack of appropriate study skills and basic science knowledge is commonplace in at-risk community college students (Harris, Hannun \& Gupta, 2004; McKee 2002). Science can be very intimidating for students, who may find it challenging and as something they may not relate to (Leornard, 2011; McKee 2002), despite the numerous ways that it's used in their everyday lives or their future careers (Mowforth, Harrison \& Morris, 2005; Yang, 2010). This usually translates to low confidence in their abilities to pursue these gateway science courses, required for most allied health programs. Add to the mix, lack of appropriate time and/or effort needed to successfully study outside the course and the challenges become magnified.

Most of our Human Anatomy and Physiology students at Bronx Community College (BCC) of the City University of New York (CUNY), as in most schools, have declared an Allied Health Major, usually nursing. Performance in Anatomy and Physiology and other prerequisite science courses is a good indicator of successful completion of Nursing programs and licensing exams (Dean \& Fischer, 1992; Newman, 1991). A high number of Anatomy and Physiology students, however, fail to meet the required $\mathrm{C}+$ or better grades needed in most allied health programs or give up in the early stages of the gateway science sequence. Most of these at-risk students do not appear to independently engage in effective study strategies, lack appropriate background knowledge in the sciences, and fail to comprehend the relevance of mastery of this subject area to their future career goals (Uno, 1988; Hinds, 1999; McKee 2002). Failure to succeed in Anatomy and Physiology and subsequent professional courses occurs despite the fact that most students have the potential to reach higher levels of learning, as evidenced in studies using individual student instruction (Bloom, 1984; Anderson \& Krathwohl, 2001). At least in part, this is because their different abilities and learning styles are not successfully addressed in the conventional large lecture class (Leonard, 2000). As 
a result Anatomy and Physiology courses have one of the worst failure and completion rates (Hopper, 2011).

To address these challenges, various initiatives have been undertaken by colleges, including offering supplement courses (Hopper, 2011), Pre A \& P workshops (Abdullahi \& Gannon, 2012), online resources (Raynor \& Iggulden, 2008), supplemental instruction such as Peer Led Team Learning (PLTL; Hughes, 2011) and Process-Oriented Guided Inquiry Learning (POGIL; Brown, 2010) or other active learning approaches such as use of skits (Ong, 2010), analogies (Sundrud \& Hueftle, 2009) and photographs (Krauss, Salame \& Goodwyn, 2010). The gains reported from these initiatives are very encouraging. For instance, introduction of POGIL, though time consuming, resulted in significant improvements in lecture exams and overall course grades and better student-student interactions (Brown, 2010). Hopper (2011) observed that, students enrolled in a one-hour supplement course meant to quickly identify at risk students, were more likely to achieve better grades and course completion rates. In a recent study, we showed that a two-week pre-Anatomy and Physiology workshop improves students' performance and attitudes to the course (Abdullahi \& Gannon, 2012). In these studies, the improvements were attributed to a change in student skills and attitudes, although the possibility that high achievers were self selected couldn't be entirely ruled out. A major challenge for supplement courses/workshops is enrollment limitations and costs. For instance, enrollment was limited to 20 students in the supplemental course (Hopper, 2011) and our workshops had similar enrollment levels in the beginning, though we increased up to 43-54 students later. While there is potential for advantages such as small group interaction and help with teaching students important skills like time management and confidence in asking/answering questions etc, this leaves out a large proportion of the general student body that need help. Individual tutorials are too costly for most Community College settings. Therefore, efforts must be made within the lecture classroom to identify and implement instructional techniques that engage students in independent learning strategies, including some of the active learning approaches above (skits, analogies, photographs etc).

One attempt to develop self-regulated learners at BCC of CUNY has been to integrate a teaching strategy called LETME (Link, Extract, Transform, Monitor and Extend; Table 1) into classroom instruction across the disciplines. This strategy integrates theories from research in study skills, reading comprehension, cognition, metacognition and critical thinking (Shenkman, 2002). While similar to the educational skills identified in Bloom's Taxonomy (Bloom, Englehart, Furst, Hill \& Krathwohl, 1956), as summarized by Giddings (1998), the LETME approach attempts to make academic skills more visible to at-risk students who have never successfully mastered basic study skills. This is accomplished by training faculty across all disciplines in teaching strategies that integrate both basic and higher order processing skills. The LETME strategy agrees with Stanley \& Waterman (2000), who argues that there is a need to involve community college students in active learning approaches that attempt to connect the topic understudy to previous knowledge or experiences. A primary goal of the LETME approach is therefore to assist novice student learners in acquiring the study skills necessary to succeed in college.

Table 1: Summary of the LETME (Link, Extract, Transform, Monitor and Extend) Approach to Learning

$\begin{array}{ll}\text { Link } & \text { Connect new information with prior knowledge. } \\ \text { Extract } & \text { Select the most critical information from a large body of material. } \\ \text { Transform } & \text { Organize and integrate new information e.g. note taking, outlining and mapping. } \\ \text { Monitor } & \text { Self-checking of comprehension and use of strategies to gauge overall learning. } \\ \text { Extend } & \text { Higher-order questioning, analysis, synthesis, and evaluation }\end{array}$

The present study investigates whether application of LETME teaching strategies can successfully improve the performance of at-risk students in Human Anatomy and Physiology. A main objective of this study was to improve the ability of students to extract and transform pertinent information from a large body of scientific facts, as they monitor their own progress. Efforts were made to link the topics to previous information and extend to new concepts. Specifically, in experimental groups open-note quizzes designed to promote these LETME skills were given at the beginning of physiology lecture classes, but prior to formal testing. Student outcomes from experimental groups were contrasted with control classes, which received additional verbal clarification of the material by the instructor. Here, we report data that shows that open note quizzes resulted in better student outcomes in performance, study habits and course completion rates. 


\section{Methods}

\subsection{Experimental Design}

In the same semester, two sections of the lecture component of Human Anatomy and Physiology I were randomly assigned to experimental and control groups. The study was then replicated in the following semester. To minimize the influence of variations in pedagogical style, the same instructor taught all groups, which received identical course content and materials. Within each semester, the same five unit lecture exams were administered to both groups on the same day. The experimental group received open note assignments. At the beginning of the semester students were instructed that open-note quizzes, which could improve unit lecture grade scores by about $4 \%$, would be given during the first 20 minutes of class, approximately once every three weeks. The open note quiz always related to the lecture material covered during the preceding two or three lecture periods, and at least four days advance notice was given. Most quizzes consisted of eight multiple-choice questions and a two to three short-sentence answer essay. Quiz questions were designed to reflect the format used in the unit lecture tests, but identical questions were not used on the unit exams. The control group received additional instructor-based clarification of lecture material instead of quizzes. In the laboratory component of the course, groups were taught by several different instructors, all of which followed the same curriculum and testing sequence.

\subsection{Assessment of Student Outcomes}

Student outcomes were assessed by their performance on five separate unit exams, and by a comparison of overall course grades achieved at the end of the semester. An end of the course, student evaluations were also given to determine whether any differences between the study habits of the two groups were apparent. In addition, the experimental group was asked to evaluate the effectiveness of the open note quizzes, if any, on their performance in the course.

\subsection{Data Analysis}

Results are shown as mean \pm SEM, with the number of observations shown in parentheses. ANOVA and Fisher PLSD post hoc tests were used to test for significant differences between control and experimental group test scores and between semesters. Test results were analyzed including and excluding students who failed to complete the course. Chi square analysis was used to analyze Likert- scaled informal student surveys (Likert, 1932). Significance was set at $\mathrm{p}<0.05$.

\section{Results}

\subsection{Effect on Course Exams}

The experimental group performed better in the lecture component of Human Anatomy and Physiology I than students in the control group. Across individual lecture tests, students given open note quizzes achieved scores significantly higher than the corresponding control group (ANOVA followed by Fisher's PLSD, $<<0.05$, Tables 2 \& 3 ). It should be noted that the scores shown do not include the open note quiz scores, as they reflect the performance on the lecture tests (Tables $2 \& 3$ ). When students who did not complete the course were included in the analysis, a significant interaction was observed between the year of study and the experimental condition (Table 2, $\mathrm{p}<0.05$ ). A similar, but non-significant trend, was also observed when only students completing the course were included in the analysis (Table 3, $\mathrm{p}>0.05$ ). While a significant main effect of open note quizzes was found, in one unit exam (Tables $2 \& 3$; Test 3, Semester $1 \&$ Test 2, Semester 2), both groups performed similarly, possibly because these tests coincided with other midterm exams at the college. 
Table 2: Effect of Open Note Quizzes on Lecture Test Grades of All Students Starting the Course. Note that the scores shown in this table reflect student performances on the lecture tests and do not therefore include open note quiz scores

\begin{tabular}{|c|c|c|c|c|c|c|}
\hline Semester & Group & $\begin{array}{l}\text { Lecture } \\
\text { Test } 1 \\
\end{array}$ & $\begin{array}{l}\text { Lecture } \\
\text { Test } 2 \\
\end{array}$ & $\begin{array}{l}\text { Lecture } \\
\text { Test } 3 \\
\end{array}$ & $\begin{array}{l}\text { Lecture } \\
\text { Test } 4\end{array}$ & $\begin{array}{l}\text { Lecture } \\
\text { Test } 5\end{array}$ \\
\hline 1 & Control & $\begin{array}{l}60.7 \\
\pm 2.6 \\
(42)\end{array}$ & $\begin{array}{l}65.8 \\
\pm 2.9 \\
(40)\end{array}$ & $\begin{array}{l}61.0 \\
\pm 2.8 \\
(35)\end{array}$ & $\begin{array}{l}57.0 \\
\pm 3.7 \\
(29)\end{array}$ & $\begin{array}{l}64.9 \\
\pm 2.9 \\
(27)\end{array}$ \\
\hline 1 & Experimental* & $\begin{array}{l}69.8 \\
\pm 2.5 \\
(45)\end{array}$ & $\begin{array}{l}76.5 \\
\pm 2.5 \\
(42)\end{array}$ & $\begin{array}{l}62.7 \\
\pm 2.5 \\
(37)\end{array}$ & $\begin{array}{l}68.9 \\
\pm 2.7 \\
(30)\end{array}$ & $\begin{array}{l}71.9 \\
\pm 2.6 \\
(28)\end{array}$ \\
\hline $2 * *$ & Control & $\begin{array}{l}66.8 \\
\pm 2.3 \\
(46)\end{array}$ & $\begin{array}{l}65.8 \\
\pm 2.4 \\
(39)\end{array}$ & $\begin{array}{l}67.6 \\
\pm 2.4 \\
(36)\end{array}$ & $\begin{array}{l}70.4 \\
\pm 2.7 \\
(34)\end{array}$ & $\begin{array}{l}62.8 \\
\pm 3.2 \\
(29)\end{array}$ \\
\hline $2 * *$ & Experimental* & $\begin{array}{l}71.1 \\
\pm 2.5 \\
(42)\end{array}$ & $\begin{array}{l}63.3 \\
\pm 2.8 \\
(40)\end{array}$ & $\begin{array}{l}70.8 \\
\pm 2.8 \\
(36)\end{array}$ & $\begin{array}{l}73.6 \\
\pm 3.3 \\
(33)\end{array}$ & $\begin{array}{l}69.6 \\
\pm 2.7 \\
(32)\end{array}$ \\
\hline
\end{tabular}

* $\mathrm{p}<0.05 \quad$ Significantly different from control

** $\mathrm{p}<0.05 \quad$ Significant interaction between year of study and results

Table 3: Effect of Open Note Quizzes on Lecture Test Grades of Students Completing the Course. Note that the scores shown in this table reflect student performances on the lecture tests and do not therefore include open note quiz scores

\begin{tabular}{|c|c|c|c|c|c|c|}
\hline Semester & Group & $\begin{array}{l}\text { Lecture } \\
\text { Test } 1\end{array}$ & $\begin{array}{l}\text { Lecture } \\
\text { Test } 2\end{array}$ & $\begin{array}{l}\text { Lecture } \\
\text { Test } 3\end{array}$ & $\begin{array}{l}\text { Lecture } \\
\text { Test } 4\end{array}$ & $\begin{array}{l}\text { Lecture } \\
\text { Test } 5\end{array}$ \\
\hline 1 & $\begin{array}{l}\text { Control } \\
(\mathrm{n}=27)\end{array}$ & $\begin{array}{l}68.4 \\
\pm 2.5\end{array}$ & $\begin{array}{l}73.4 \\
\pm 3.0\end{array}$ & $\begin{array}{l}64.1 \\
\pm 3.0\end{array}$ & $\begin{array}{l}58.0 \\
\pm 3.9\end{array}$ & $\begin{array}{l}64.9 \\
\pm 2.9\end{array}$ \\
\hline 1 & $\begin{array}{l}\text { Experimental* } \\
(\mathrm{n}=30)\end{array}$ & $\begin{array}{l}75.2 \\
\pm 2.8\end{array}$ & $\begin{array}{l}80.6 \\
\pm 3.1\end{array}$ & $\begin{array}{l}65.7 \\
\pm 2.6\end{array}$ & $\begin{array}{l}68.9 \\
\pm 2.8\end{array}$ & $\begin{array}{l}71.9 \\
\pm 2.6\end{array}$ \\
\hline 2 & $\begin{array}{l}\text { Control } \\
(\mathrm{n}=29)\end{array}$ & $\begin{array}{l}73.3 \\
\pm 2.7\end{array}$ & $\begin{array}{l}70.8 \\
\pm 2.6\end{array}$ & $\begin{array}{l}68.8 \\
\pm 2.7\end{array}$ & $\begin{array}{l}71.7 \\
\pm 2.9\end{array}$ & $\begin{array}{l}62.8 \\
\pm 3.2\end{array}$ \\
\hline 2 & $\begin{array}{l}\text { Experimental* } \\
(\mathrm{n}=32)\end{array}$ & $\begin{array}{r}75.9 \\
\pm 2.5 \\
\end{array}$ & $\begin{array}{r}68.0 \\
\pm 2.7 \\
\end{array}$ & $\begin{array}{r}74.6 \\
\pm 2.7 \\
\end{array}$ & $\begin{array}{r}74.3 \\
\pm 3.4 \\
\end{array}$ & $\begin{array}{r}69.6 \\
\pm 2.7 \\
\end{array}$ \\
\hline
\end{tabular}

$* \mathrm{p}<0.05 \quad$ Significantly different from control.

\subsection{Effect on Course Grades}

Since the worst unit test grade was dropped to obtain a final lecture average for the course, ANOVA was also performed on the final lecture average. Without the open note quizzes, the experimental groups achieved a higher final lecture average than the control groups (75.1 $\pm 1.7 ; n=62$ versus $71.2 \pm 1.7 ; n=56$, respectively). This difference approached, but did not reach statistical significance ( $p>0.05$, data not shown). The open note assignments increased the average final lecture grade by $4 \%$ (data not shown). This improved the overall course grade in the experimental group by an average of $2 \%$, compared to the control group, since the lecture grade accounted for $50 \%$ of the final course grade.

Comparing overall course grades, a larger percentage of students in the experimental group both passed the course, and achieved a grade of $\mathrm{C}+$ or higher, compared to the control group (Table 4, Figure 1). This improvement in grade distribution appeared due, in part, to a decrease in administrative grades, which includes all students who did not complete the course, and not to a significant change in the overall failure rate. In general, successful students in the 
experimental group achieved final grades higher than their peers in the control group. For example, $42 \%$ of the experimental group earned a grade of B or better, compared to only $18 \%$ of students in the control group (Figure 1). The percentage of students obtaining a grade of $\mathrm{C}$ or below was similar in both groups (Table 4, Figure 1). These results cannot be accounted for solely on the basis of the open note quizzes, which only accounted for $2 \%$ of the overall grade.

Table 4: Comparison of Final Anatomy and Physiology Grade Distribution between Control and Experimental Groups

\begin{tabular}{|c|c|c|c|c|c|c|}
\hline Group & $\begin{array}{l}\text { Total } \\
\text { Passing }\end{array}$ & $\%$ & $\mathrm{~A}+$ to $\mathrm{C}+$ & C to D- & $\mathrm{F}$ & $\begin{array}{l}\text { Administrative } \\
\text { Grade* }\end{array}$ \\
\hline $\begin{array}{l}\text { Control } \\
(\mathrm{n}=91)\end{array}$ & $53.9 \%$ & & $28.6 \%$ & $25.3 \%$ & $7.7 \%$ & $38.5 \%$ \\
\hline $\begin{array}{l}\text { Experimental } \\
(\mathrm{n}=87)\end{array}$ & $65.5 \%$ & & $44.8 \%$ & $20.7 \%$ & $5.7 \%$ & $29.9 \%$ \\
\hline
\end{tabular}

* Administrative grade including withdrawals and debarments.

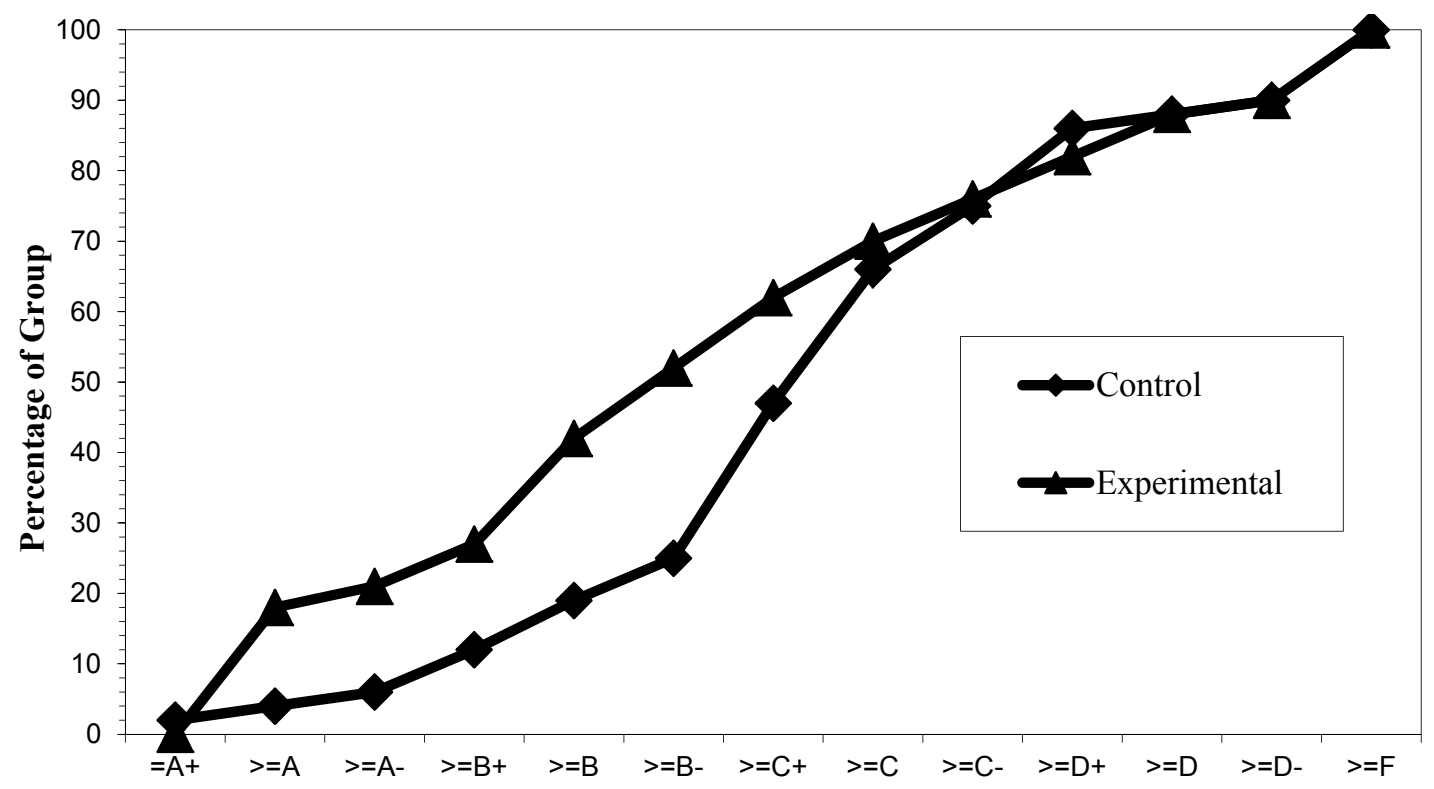

Final Grade

Figure 1: Effect of Open Note Quizzes on Final Grade Distribution

\subsection{Student Surveys}

Anonymous student surveys, conducted at the end of the course, indicated that there was a non-significant tendency for the experimental group to have slightly better study habits. The experimental group was more likely to use the textbook, re-write their notes, participate in study groups and prepare/study before coming to the class. For instance, on the question of study hours per week using the textbook, an average score \pm SEM of $2.79 \pm 0.15$ was observed for the experimental group $(\mathrm{n}=53)$ compared to $2.64 \pm 0.12$ for the control $(\mathrm{n}=55)$. However, on the Likert scale used $(1=$ 0 hours, $2=1-3$ hours, $3=4$ to 7 hours, $4=8$ to 12 hours, $5=$ more than 12 hours), both of these values approximate 3 , which represents about 4 to 7 hours of study per week. Similarly, slightly favorable experimental group observations were made for the question of reading the material before coming to class, $2.53 \pm 0.15 \mathrm{vs.} 2.35 \pm 0.17$ for the experimental and control groups respectively.

The trend also held when a different Likert scale was used $(1=$ never, $2=$ not very often, $3=$ sometimes, $4=$ most of the time, $5=$ all of the time) to gauge student opinions. An average score of $3.06 \pm 0.17(\mathrm{n}=53)$ was observed for the experimental group, when asked how often they re-wrote their notes after class, compared to only $2.69 \pm 0.16(\mathrm{n}=55)$ for the control group. Both groups of students had their lowest score on the question of study groups outside the 
classroom, but the experimental group tended to be more favorable at $2.30 \pm 0.18(\mathrm{n}=53)$ relative to control group's $1.95 \pm 0.16(\mathrm{n}=55)$. Surprisingly, $35 \%$ of all students stated that although they knew the amount of time required to study the material prior to the start of the course, they had not planned enough time to study. Approximately $50 \%$ of all students felt they had planned enough independent study time.

The majority of students given open note assignments recognized that their notes helped them answer the quizzes, with a high average score of $4.65 \pm 0.08$ that approximates an opinion of "all of the time" on the Likert scale used (Table 5). Similar opinions were expressed on the questions of whether the open note quizzes helped in preparing them for the actual lecture exams and helped master the course (Table 5). A large percentage of students reported that their study habits had changed as a result of these assignments (more than just reading notes the night before the quiz); with an overall opinion index that approximates "most of the time". In addition, most students rewrote their notes in order to prepare for the open note quizzes at least some of the time. In this regard, student comments inferred they had learned that accurate note taking was an effective use of their independent study time.

Table 5: Students Ratings of the Effectiveness of the Open Note Quizzes as Study Aids for Studying the Lecture Material

\begin{tabular}{lll}
\hline Open Note Quizzes & $\begin{array}{l}\text { Experimental } \\
\text { Mean } \pm \text { SEM }\end{array}$ & $(\mathbf{n = 5 1 )}$ \\
\hline Did you study for them? & $3.57 \pm 0.14$ \\
Did you re-write your notes for them? & $3.22 \pm 0.19$ \\
Did they help you with Exam preparation? & $4.55 \pm 0.11$ \\
Did your notes help answer them? & $4.65 \pm 0.08$ \\
Did they change your study habits? & $3.76 \pm 0.16$ \\
Did they help you master the course? & $4.51 \pm 0.10$ \\
\hline
\end{tabular}

Likert Scale: $1=$ never, 2 = not very often, $3=$ sometimes, $4=$ most of the time, $5=$ all of the time). Results shown are mean \pm standard error of mean (SEM).

\section{Discussions}

Introduction of LETME study skills into the physiology component of the Anatomy and Physiology course significantly improved student performance. This was reflected in the higher test and course grades, and the increased number of students completing the course. The present application of LETME was designed to engage the students' in extracting and transforming pertinent information from a large body of physiological information, and to independently monitor their own performance. Thus the use of open note quizzes was predicted to encourage students to independently reorganize, transform and study their notes prior to formal testing of the material (Shenkman, 2002; Harris et al., 2004).

The improvements in student grades shown in the present study are similar to those predicted by Bloom (1984). In this article, mastery learning, where conventional instruction is supplemented by formative tests given for the purposes of feedback followed by corrective procedures, was shown to significantly increase student learning. The LETME approach to learning shows parallels with the mastery learning approach. Since at-risk students must first master basic study skills, mastery learning in this population could be defined as the successful acquisition and application of basic learning skills that are usually assumed and required in higher academic settings. Several additional factors may contribute to the improved performance of students exposed to LETME teaching strategies. Given the heterogeneous nature of at risk students, the possibility that the present results reflect different inherent academic abilities between the experimental and control groups cannot be entirely discounted.

However, the results of the present study suggest that students exposed to LETME strategies increased their ability to study independent of formal instruction. Many at risk students avoid the challenge of extracting material that is more important, despite evidence that this learning skill has been shown to maximize the efficiency of their studying effort (Bean, 1996; Wittrock, 1986). Students overwhelmingly stated in surveys that the quizzes helped them prepare for the course exams and master the course, with a high proportion of students also changing their study habits. This is a positive outcome as poor study habits is a major predictor of poor performance (McKee, 2002) and better preparation is correlated with success in the sciences (Abdullahi \& Gannon, 2012; Harris et al., 2004; Hopper, 2011). It is encouraging to note that several students in the present study commented that they now felt more confident in self-monitoring their own performance. Many students also informally reported that the use of open-note quizzes 
helped to decrease their fear and anxiety of formal tests. Fear of science, accompanied by self-doubt and insecurity, are factors that contribute to the failure of high-risk students to progress in college science courses (Hinds, 1999; McKee 2002). In all likelihood, exposure to open-note quizzes provides a type of prior learning experience that, by increasing student confidence in their ability to master the material, contributes to the success of the present study.

The success or failure of the quiz format in improving student performance is also dependent on many variables. In the present study, it seems likely that the effective use of quizzes reflects the LETME teaching strategy used. However, conflicting results have been reported on the use of the quiz format as a means to improve student outcomes in college science courses, as discussed by Haberyan (2003). In the present study, while a significant main effect was observed across multiple tests, it was not apparent when only student final lecture averages were compared. Clearly the design of the study, including sample size, impacts on the outcomes. The nature of questions posed in both quizzes and tests will also determine whether the quiz structure is an effective learning strategy. Presumably, reinforcement of learning strategies the student has already fully mastered and applied will not improve their academic performance. Indeed, repeated quiz formats were shown to adversely affect learning in medical school students, where repetition of material apparently caused students to lose interest (Tan, 1992). Learning strategies that are unrealistically challenging are also unlikely to meet with success. For example, use of an instructor-guided, student-generated questioning technique in a community college Human Anatomy and Physiology lecture class did not improve the critical thinking skills of at- risk students (Arburn \& Bethel, 1999), although it had generally been successfully applied in other academic settings (Rosenshine, Meister \& Chapman, 1996). However, POGIL methods where specific students were given clear roles in an inquiry based approach and an experienced student-guided supplemental PLTL approaches have recently been more successful in A \& P (Brown, 2010; Hughes, 2011). Thus continuing efforts must be made to identify testing techniques, and teaching strategies, appropriate for the at-risk community college student.

Across all academic levels there is a wide (and growing) gap between most students' ability to memorize names and facts and to apply this information to the course content under study (Leonard, 2000; Lunsford \& Herzog, 1997). The quiz and test questions used in the present study were mainly constructed based on the student's need to acquire basic course content (levels 1 and 2 on blooms taxonomy i.e. knowledge and comprehension), and did not directly address higher order processing skills (Blooms et al., 1956; Anderson \& Krathwohl, 2001). However, even in this context, high-risk students were probably using higher order cognitive strategies. Many of the students at BCC are second language learners, and the majority of all students have very limited science backgrounds. There are no science prerequisites required to enroll for the Human Anatomy and Physiology course, whose only prerequisites are minimal college level reading, mathematics and writing skills. At-risk students must, by necessity, therefore use higher level processing skills just to comprehend the scientific language and content contained in the question posed, albeit at a level far below where most instructors would like.

One assumption of the LETME model is that when at-risk students are repeatedly exposed to effective learning strategies they will independently apply them to other areas of their learning. Others have shown that students may not continue to use useful strategies outside of the context in which they are taught (Garner, 1990; Derry \& Murphy, 1986). In common with their younger peers, adult learners tend to focus their study efforts towards passing the test, and not on the acquisition of the knowledge and skills they will need to proceed to the next level of their education. In addition, at risk students do not see the interrelationships between general education courses, the basic sciences and their potential careers (Ertmer\& Dillon, 1998; Leornard, 2011; Mowforth, Harrison \& Morris, 2005; Yang, 2010). Hopefully across the discipline application of LETME, coupled with quizzes that gain an immediate, but not intimidating, reward will assist students in recognizing and utilizing learning strategies to apply in all science-related areas.

\section{Conclusions}

In summary, introduction of LETME resulted in better student outcomes in course exams, overall grades, attrition rates and attitudes. Surveys showed that LETME was very popular with students, as they got the opportunity, to work independently with the textbook and other resources to answer open note quizzes. Students overwhelmingly stated that LETME helped them with exam preparation and mastering the course. This may explain the significantly higher performance of experimental LETME sections, relative to the control. The effect wasn't as much on the overall course grades, as the lecture portion of the course where LETME was used, only accounted for $50 \%$ of the grade, with the lab portion identical for experimental and control groups.

While these improvements are positive gains, fellow faculty members were concerned that course content was lost at 
the expense of the class time needed to administer and discuss the open note quizzes. Indeed, the Anatomy and Physiology textbook used in this course, with accompanying aids, was designed and selected to enable students to self learn the material, and contains appropriate end of chapter summaries and study questions. The conflict over content versus comprehension is obviously a major challenge for any instructor, as more active learning approaches are introduced to A \& P. Teaching domain specific content such as Human Anatomy and Physiology clearly cannot be substituted for teaching learning skills. Recognition and comprehension of the basic facts and information must precede higher order learning skills (Giddings, 1998) but each factor relies upon the other (Weinstein \& Mayer, 1986). The decision on whether or not the gains shown in the present study are worth the time taken away from formal lecture instruction, and the impact of additional preparation and grading on other responsibilities of the instructor, will be determined by the priorities of the individual instructor, department and college.

\section{Acknowledgements}

This work is an extension of the Reading, Learning and Thinking Across the Curriculum Workshop, part of the Center for Teaching Excellence funded under a Title V grant to BCC. We would also like to acknowledge fellow Biology faculty, specifically Carlos Liachovitzky, Seher Atamturktur and Shylaja Akkaraju.

\section{References}

Abdullahi, A., \& Gannon, M. (2012). Improving college students' success in gateway science courses: lessons learned from an anatomy and physiology workshop. American Journal of Health Sciences, 3(3), 159-168. Retrieved from http://journals.cluteonline.com/index.php/AJHS/article/view/7134/7208

Anderson, L. W., \& Krathwohl, D. R. (2001). A taxonomy learning, teaching, and assessing: A revision of Bloom's taxonomoy of educational objectives. New York: Longman. Retrieved from http://www.odu.edu/educ/roverbau/Bloom/blooms_taxonomy.htm

Arburn, T.M., \& Bethel, L.J. (1999). Assisting at-risk community college students: Acquisition of critical thinking learning strategies. Educational Resources Information Center (ERIC), EDRS \# 448-016.

Bean, J. C. (1996). Engaging Ideas. The Professor's Guide to Integrating Writing, Critical Thinking, and Active Learning in the Classroom. San Francisco: Ossey-Bass.

Brown, P.J.P. (2010). Process-oriented guided-inquiry learning in an introductory anatomy and physiology course with a diverse student population. Advances in Physiology Education, 34, 150-155. http://dx.doi.org/10.1152/advan.00055.2010

Bloom, B., Englehart, M., Furst, E., Hill, W., \& Krathwohl, D. (1956). Taxonomy of Educational Objectives, The classification of educational goals. Handbook I: Cognitive Domain. New York, Toronto: Longmans, Green.

Bloom, B.S. (1984). The search for methods of group instruction as effective as one-to-one tutoring. Educational Leadership, 41(8), 4-17. $\quad$ Retrieved from http://www.ascd.org/ASCD/pdf/journals/ed_lead/el_198405_bloom.pdf

Dean, J.H., \& Fischer, S. E. (1992). Nursing predictors study, phase one. Educational Resources Information Center (ERIC), EDRS \# 349-036.

Derry, S. J., \& Murphy, D.A. (1986). Designing systems that train learning ability: From theory to practice. Review of Educational Research, 56(1), 1-39. http://dx.doi.org/10.3102/00346543056001001

Ertmer, P.A., \& Dillon, D.R. (1998). Shooting in the dark versus breaking it down: Understanding student's approaches to case-based instruction. Qualitative Studies in Education, 11(4), 605-622. http://dx.doi.org/10.1080/095183998236502

Garner, R. (1990). When children and adults do not use learning strategies: Toward a theory of settings. Review of Educational Research, 60(2), 517-529. http://dx.doi.org/10.3102/00346543060004517

Giddings, L.R. (1998). Beyond E.D. Hirsch and Cultural Literacy: Thinking skills for cultural awareness. Community Review, 16, 109-117.

Haberyan, K.A. (2003). Do weekly quizzes improve student performance on General Biology exams? The American Biology Teacher, 65(2), 110-115.

Harris, D.E., Hannum, L., \& Gupta, S. (2004). Contributing factors to student success in Anatomy and Physiology: 
Lower outside workload and better preparation. American Biology Teacher, 66(3), 168-175. Retrieved from http://www.jstor.org/discover/10.2307/4451650?uid=3739832\&uid=2129\&uid=2\&uid=70\&uid=4\&uid=373925 6\&sid $=21102312993667$

Hinds, I.L. (1999). Special needs of adult learners in science (Biology). Community Review, 17, 42-48. Retrieved from http://connection.ebscohost.com/c/articles/5458026/special-needs-adult-learners-science-biology

Hopper, M. (2011). Student Enrollment in a Supplement Course for Anatomy and Physiology Results in Improved Retention and Success. Journal of College Science Teaching, 40(3), 70-79. Retrieved from http://www.questia.com/library/1G1-246179616/student-enrollment-in-a-supplement-course-for-anatomy

Hughes, K. S. (2011). Peer-Assisted Learning Strategies in Human Anatomy \& Physiology. The American Biology Teacher, 73(3), 144-147. http://dx.doi.org/10.1525/abt.2011.73.3.5

Krauss, D.A., Salame, I.I., \& Goodwyn, L.N. (2010). Using Photographs as Case Studies to Promote Active Learning in Biology. Journal of College Science Teaching, 40(1), 72-76. Retrieved from http://www.questia.com/library/1G1-235194606/using-photographs-as-case-studies-to-promote-active

Leonard, W.H. (2000). How do college students best use science? Journal of College Science Teaching, 29(6), 385-388.

Leornard, W. (2011). Eight big challenges for effective student learning of biology. The American Biology Teacher, 73(5), 258-259. http://dx.doi.org/10.1525/abt.2011.73.5.2

Likert, R. (1932). A Technique for the Measurement of Attitudes. Archives of Psychology, 140, 1-55.

Lunsford, B.E., \& Herzog, M.J.R. (1997). Active learning in Anatomy and Physiology. Student reactions and outcomes in a nontraditional A\&P course. The American Biology Teacher, 59(2), 80-84. http://dx.doi.org/10.2307/4450254

McKee, G. (2002). Why is biological science difficult for the first-year nursing students? Nurse Ed. Today, 22, 251-257. Retrieved from http://www.ncbi.nlm.nih.gov/pubmed/12027607

Mowforth, G., Harrison, J., \& Morris, M. (2005). An investigation into adult nursing students' experience of the relevance and application of behavioural sciences (biology, psychology and sociology) across two different curricula. Nurse Education Today, 25, 41-48. http://dx.doi.org/10.1016/j.nedt.2004.09.009

Neuman, L.H. (1991). The relationship between admission/academic achievement variables and pass/fail performance on the National Council Licensure Examination for Registered Nurses (NCLEX-RN) in an LPN-RN program. Ph.D. diss., University of Maryland, College Park.

Ong, B. (2010). A Play of Protein Synthesis in the Classroom. The American Biology Teacher, 72(9), 564-566. http://dx.doi.org/10.1525/abt.2010.72.9.8

Raynor, M., \& Iggulden, H. (2008). Online anatomy and physiology: piloting the use of an anatomy and physiology e-book-VLE hybrid in pre-registration and post-qualifying nursing programmes at the University of Salford. Health Information and Libraries Journal, 25, 98-105. http://dx.doi.org/10.1111/j.1471-1842.2007.00748.x

Rosenshine, B., Meister, C., \& Chapman, S. (1996). Teaching students to generate questions: A review of the intervention studies. Review of Educational Research, 66(2), 181-221. http://dx.doi.org/10.3102/00346543066002181

Shenkman, H.L. (2002). Reading, learning, and thinking seminars: A template for faculty training. Learning Abstracts, 5(1).

Stanely, E.D., \& Waterman, M.A. (2000). Lifelines online - curriculum and teaching strategies for adult learners. Integrating information technology with problem solving pedagogies. Journal of College Science Teaching, 29(5), 306-310.

Sundrud, R.B., \& Hueftle, K. (2009). Essential Analogies in Human Anatomy \& Physiology. The American Biology Teacher, 71(9), 554-557. http://dx.doi.org/10.2307/20565380

Tan, C.M. (1992). An evaluation of the use of continuous assessment in the teaching of physiology. Higher Education, 23, 255-272. http://dx.doi.org/10.1007/BF00145016

Uno, G.E. (1988). Teaching college and college-bound biology students. The American Biology Teacher, 50(4), 213-216. http://dx.doi.org/10.2307/4448711 
Weinstein, C.E., \& Mayer, R.E. (1986).The teaching of learning strategies. In M.C. Wittrock (Ed.), Handbook of Research on Teaching (pp. 315-327). New York: Macmillan.

Wittrock, M.C. (1986). Handbook of Research on Teaching. New York: Macmillan.

Yang, L. (2010). Toward a Deeper Understanding of Student Interest or Lack of Interest in Science. Journal of College Science Teaching, 39(4), 68-77. Retrieved from http://connection.ebscohost.com/c/articles/48444171/toward-deeper-understanding-student-interest-lack-interest -science 